Table 2. URINARY Gestrogen TITRE UNDER NORMal STORAGE

\begin{tabular}{|c|c|c|c|}
\hline & Initial & $\begin{array}{l}2 \text { days at room } \\
\text { temperature }\end{array}$ & $\begin{array}{l}6 \text { days } \\
\text { at } 4^{\circ} \mathrm{C} .\end{array}$ \\
\hline $\begin{array}{l}\text { Total cestrogen } \\
\text { Mean } \\
\text { S.D. }\end{array}$ & $\begin{array}{c}14 \cdot 0 \\
(6) \\
\pm 16.0\end{array}$ & $\begin{array}{c}15 \cdot 1 \\
(6) \\
\pm 16.5\end{array}$ & $\begin{array}{c}14 \cdot 2 \\
(6) \\
+16 \cdot 7\end{array}$ \\
\hline
\end{tabular}

No. of duplicate estimations in parentheses. Results calculated as $\mu \mathrm{gm} . / 24 \mathrm{hr}$.

free ostrogens after ten weeks at room temperature; and from 62 to 74 per cent of the oestrone fraction, 0-45 per cent of the cestradiol-17 $\beta$ fraction, and 62-100 per cent of the oestriol fraction were found to be in the free form.

The increase in the cstrogen content of stored wine could possibly be accounted for by the transformation of one or more of the oestrogen metabolites known to be present in human uxine but not measured by Brown's mothod. After four woeks on the bench or at $4^{\circ} \mathrm{C}$. an increase from zero to $12 \mu \mathrm{gm}$. of cestriol was found in a specimen to which 16 $\alpha$-hydroxynestrone had been added, compared with no change in a control urine. Micrococci and diphtheroids were shown to be present in the urine but no attempt was made to determine whether the steroid transformation was due to the presence of these micro-organisms or to the increase in the alkalinity of the urine.

In normal circumstances changes have not been found to occur providing the urine is not kept for more than two days at room temperature or for more than a woek at $4^{\circ} \mathrm{C}$. (Tablo 2).

Although there were slight individual variations there is no significant difference between the three sets of results.

If urine is stored for any length of time, hydrolysis of the conjugates and destruction or transformation of the oestrogens may occur. The changes are not predictable or constant and unless analyses are carried out within two days at room temperature, or within one week at $4^{\circ} \mathrm{C}$., the results may have little reference to the original titre of œstrone, œestradiol. $17 \beta$ and cestriol. However, it has been. shown ${ }^{3}$ that no loss of cestrogen occurred in a single specimen of urine stored at $-10^{\circ} \mathrm{C}$. for two months.

$$
\begin{aligned}
& \text { Y. A. LEON } \\
& \text { R. D. BULBRoOK } \\
& \text { F. C. GreENWOOD }
\end{aligned}
$$

Clinico-Pathological Laboratories,

Imperial Cancer Researeh Fund,

Royal College of Surgeons,

London, W.C.2.

Nov. 25.

${ }^{1}$ Cohen, S. L., J. Biol. Chem., 112, 147 (1951).

${ }^{2}$ Brown, J. B., Bulbrook, R. D., and Greenwood, F. C., J. Endocrinol., 16, 49 (1957).

${ }^{3}$ Brown, J. B., Bulbrook, R. D., and Greenwood, F. C., J. Endocrinol.,
$\mathbf{1 6}, 41(1957)$.

\section{Method for testing the Influence of Drugs and Physical Agents upon Mitosis}

JoLLY ${ }^{1}$ described how to obtain a convenient number of erythroblastic mitoses in the circulating blood of various species of Triturus. The new techniques now made available by phase-contrast microscopy induced us to study these cells with time-lapse photography and micro-cinematography in order to obtain direct evidence of the mechanism of normal and artificially influenced mitosis.
The method can be summarized as follows. According to Jolly the newts are left absolutely without food for 2-6 months ; after this period the animals are put in a thermostatic enclosure at $26^{\circ} \mathrm{C}$. and fed for some days with earthworms. Generally, between the second and fourth day of feeding a good number of erythroblastic mitoses appear in the circulating blood of the newts. At this moment a blood smear is taken from the tail of the animals and stained as a control. Afterwards the newts are treated according to the aims of each particular experiment (intraperitoneal injections, exposure to radiations or gases, etc.) ; at various intervals small drops of blood are then taken from the tail of the animals, put on a slide, covered gently with a cover slide and sealed with paraffin.

The preparations are put under the phase-contrast microscope for time-lapse photography or cinematography ; in order to keep the temperature constant during observation, the microscope is put in a special thermostatic enclosure. At the same time blood smears are prepared and stained. In certain cases it may be also advisable to act directly on the surviving erythroblasts of an untreated newt, adding the substance to the blood drop or exposing it to radiations, gases, etc.

Thus it is possible to follow and to document with films or photographs the course of mitosis and the various alterations eventually induced. Additional results are obtained from the stained smears.

Obviously, a great number of modifications to the method we have outlined may be necessary. In fact, our test is adaptable to many different experimental conditions, but is particularly suited when clear morphological evidence is needed. A series of detailed papers is in preparation, dealing with normal mitosis and the influence of various substances and physical agents upon it.

Elio Guido Rondanteli

Pasquale Gorini

Domenico Pecorari

Clinica Medica Universitaria,

Pavia.

Nov. 10.

${ }_{1}^{1}$ Jolly, J., Arch. Anat. Micr., 6, 455 (1903-4).

\section{Splitting of the Electrophoretic Pattern of Serum Albumin during Short-term Action of Pepsin at Room Temperature}

THE heterogeneity of serum albumins consisting of several molecular sub-units has been established by chemical as well as by electrophoretic assays. However, while chemical fractionation of serum albumins led to well-identified products, electrophoretio procedures did not show equally consistent results. In this latter case, the separation of the sub-units was found to vary with $p \mathrm{H}$, ionic strength, length of run, and other factors not well understood ${ }^{1}$. It could be shown, moreover, that the splitting of albumin into a number of boundaries is a reversible process and does not represent denaturation on artefacts.

A similar but apparently irreversible splitting of serum albumin into molecular sub-units, by the shortterm action of pepsin, is demonstrated in the present electrophoretic studies carried out by Tiselius's moving boundary method.

The analyses were initiated with crystalline bovine serum albumin (Armour). $100 \mathrm{mgm}$. albumin was dissolved in approximately $10 \mathrm{ml}$. distilled water 